\title{
IMPLEMENTASI PENDIDIKAN KARAKTER DALAM PAI DI SDIT LUQMANUL HAKIM BANDUNG
}

\author{
Fitriani Nafiah, ${ }^{*}$ \\ Ahmad Syamsu Rizal, Syahidin \\ Program Studi Ilmu Pendidikan Agama Islam, \\ Fakultas Pendidikan Ilmu Pengetahuan Sosial, Universitas Pendidikan Indonesia \\ *Email: pipit.fitrianinafiah@gmail.com
}

\begin{abstract}
ABSTRAK
Artikel ini dilatarbelakangi oleh para pelajar yang saat ini mulai lemah karakternya sehingga di usia belia sudah gampang putus asa, terpengaruh oleh hal-hal negatif, dan sebagainya. Pelaksanaan pendidikan karakter menjadi salah satu hal yang harus dilaksanakan di jenjang pendidikan manapun, khusunya di jenjang pendidikan dasar. Hal ini dikarenakan pendidikan dasar menjadi pondasi utama bagi tumbuh kembangnya generasi muda dimasa depan. Pada saat ini, nilai-nilai pendidikan karakter sudah mulai diimplementasikan di sekolah dalam berbagai mata pelajaran, khususnya dalam mata pelajaran Pendidikan Agama Islam. Penelitian ini bertujuan untuk mengetahui lebih dalam implementasi pendidikan karakter dalam PAI di SDIT Luqmanul Hakim Bandung. Metode yang digunakan ialah metode deskriptif melalui pendekatan kualitatif. Teknik pengumpulan data melalui observasi, wawancara, studi dokumentasi, dan triangulasi. Teknik analisis data dengan cara reduksi data, display data, dan kesimpulan. Pada perencanaan pendidikan karakter dalam PAI ketika pembelajaran di kelas mengacu pada silabus dan RPP PAI, namun tidak ada perbedaan dalam silabus dan RPP PAI. Dengan adanya evaluasi mingguan dan buku penghubung, memberikan dampak yang baik kepada siswa sehingga akhlak siswa terpantau baik secara langsung oleh setiap guru baik di lingkungan sekolah maupun di rumah. Berdasarkan hasil penelitian secara umum bahwa implementasi pendidikan karakter dalam PAI sudah cukup baik terlihat dari siswa yang menunjukkan akhlak baik dan guru yang memberikan teladan baik kepada siswanya. Siswa menunjukkan sikap mandiri, jujur, bertanggungjawab, disiplin, peduli lingkungan. Saling menghormati, dan saling menyayangi antar sesama teman dan guru.
\end{abstract}

Kata Kunci: Pendidikan karakter, Pendidikan Agama Islam, SD Islam Terpadu 


\section{PENDAHULUAN}

Keberhasilan suatu bangsa dalam mencapai tujuan pendidikan, tidak hanya ditentukan oleh melimpahnya puluhan atau bahkan jutaan orang yang berpendidikan bagus, baik dari segi tingginya tingkat pendidikan bahkan ilmuan-ilmuan pintar dalam pengetahuan. Bangsa yang besar dapat dilihat dari kualitas/karakter bangsa itu sendiri.

Dalam UU Sistem Pendidikan Nasional Tahun 2003 menyebutkan bahwa "pendidikan bertujuan mengembangkan kemampuan dan membentuk watak serta peradaban bangsa yang bermartabat dalam rangka mencerdaskan kehidupan bangsa, dan bertujuan untuk berkembangnya potensi peserta didik

tingkah laku atau tabiat. Dalam Islam, pendidikan karakter/akhlak menjadi hal yang diutamakan. Sebagaimana sabda Rasūlullāh Saw yang artinya, "sesungguhnya orang pilihan di antara kamu ialah orang yang baik akhlaknya”. Dalam al-Qur'ān surah al-Qalam : 4 :

Artinya :

"dan Sesungguhnya Engkau (ya Muhammad) benar-benar mempunyai berbudi pekerti yang luhur"(Q.S. Al-Qalam [68] : 4 ).

Dari ayat tesebut, Muḥammad memiliki budi pekerti yang luhur. Disinilah figur Rasūlullâh Saw sebagai panutan dengan memberikan teladan yang baik. Menurut Syahidin (2009, hal.73), salah satu misi penting yang diemban Rasūlullāh ke dunia ini adalah menyempurnakan akhlak manusia, sebagaimana sabdanya: 'sesungguhnya aku diutus ke muka agar menjadi manusia yang beriman dan bertakwa kepada Tuhan Yang Maha Esa, berakhlak mulia, sehat, berilmu, cakap, kreatif, mandiri, dan menjadi warga negara yang bertanggung jawab". Berdasarkan tujuan pendidikan dalam UU Sistem Pendidikan Nasional Tahun 2003, bahwa pendidikan selain bertujuan mengembangkan kemampuan juga membentuk watak atau karakter. Karakter diartikan sebagai tabiat, watak, sifat-sifat kejiwaan, akhlak atau budi pekerti yang membedakan seseorang dengan yang lain. Karakter adalah watak, sifat yang memang mendasar pada diri seseorang (Andayani, 2012, hal. 11).

Dalam pandangan Islam, karakter itu sama dengan akhlak. Akhlak diartikan sebagai budi pekerti, bumi ini adalah untuk menyempurnakan akhlak manusia'. Diantara akhlak mulia yang sering disebut dalam al-Qur'ān tercermin dalam sifat kerasulan yang ada pada pribadi nabī Muḥammad seperti fațānah, amānah, sidīq, tablīg. Rasūlullāh menjadi teladan yang baik, maka dari itu akhlak tidak diragukan lagi memiliki peranan besar dalam kehidupan manusia.

Akhlak menempati kedudukan penting dan dianggap memiliki fungsi dalam memandu kehidupan masyarakat, Sebagaimana Firman Allah dalah Q.S. An-Nahl : 90, Artinya :

"Sesungguhnya Allah menyuruh (kamu) berlaku adil dan berbuat kebajikan, memberi kepada kaum kerabat, dan Allah melarang dari perbuatan keji, kemungkaran dan permusuhan. Dia memberi pengajaran kepadamu agar kamu dapat mengambil pelajaran". (QS.AnNahl/16 : 90) 
Dalam sejarah Islam, Rasūlullāh Muhammad Saw, nabī terakhir dalam ajaran Islam, menegaskan bahwa misi utamanya dalam mendidik manusia adalah untuk mengupayakan pembentukan karakter yang baik (good character) (Andayani, 2012, hal. 30).

Secara garis besar karakter dapat didefinisikan sebagai akhlak, karakter mengenal dua sisi karakter baik dan karakter buruk, begitupun akhlak yang terdiri dari akhlak terpuji (akhlāqul mahmūidaћ) dan akhlak tercela (akhlāqul mażmūmaћ). Akhlak yang mulia merupakan inti dari ajaran Islam, sebagaimana terdapat dalam alQur'ān adalah akhlak yang betumpu keimanan kepada Allah (hablum minallāh), dan keadilan sosial (hablum minannās). Jika di dalam alQur'ān terdapat ajaran keimanan, ibadah, sejarah, dan sebagainya, maka yang akan dituju adalah agar dengan ajaran tersebut akan terbentuk akhlak yang mulia. Orang yang beriman menurut al-Qur'ān adalah orang yang harus membuktikan keimanannya dalam bentuk amal salih, bersikap jujur, amanah, berbuat adil, kepedulian sosial dan sebagainya (Nata, 2012, hal. 216).

Sudah jelas bahwa karakter dalam perspektif Islam adalah akhlak. Akhlak mulia yang bersumber pada al-Qur'ān dan hadis̀. Membentuk karakter seharusnya dimulai sejak dini atau anak-anak karena pada masa itu anak-anak mudah ditanamkan dan dibentuk karakternya dengan karakter yang baik atau akhlak yang baik. Para ahli pendidikan di Indonesia umumnya bersepakat bahwa pendidikan karakter sebaiknya dimulai sejak usia anak-anak (golden age), karena usia ini terbukti sangat menentukan kemampuan anak dalam mengembangkan potensinya.

Hasil penelitian menunjukkan bahwa sekitar 50\% variabilitas kecerdasan orang dewasa sudah terjadi ketika anak berusia 4 tahun. Peningkatan $30 \%$ berikutnya terjadi pada usia 8 tahun, dan $20 \%$ sisanya pada pertengahan atau akhir dasawarsa kedua. Oleh karena itu sudah sepatutnya pendidikan karakter dimulai dalam lingkungan keluargayang merupakan lingkungan awal bagi pertumbuhan anak, dan dalam implementasinya pendidikan karakter umumnya dikembangkan di lingkungan sekolah (Hariyanto, 2012, hal. 110).

Dalam pandangan Islam tahapan-tahapan pengembangan dan pembentukan karakter dimulai sedini mungkin, sebagaimana dijelaskan oleh Rasūlullâh dalam sabdanya : 'muliakan anak-anakmu dan didiklah mereka dengan adab (budi pekerti) yang baik' (H.R.Ibnu Majah). Pada usia 5-6 tahun, anak dididik budi pekerti, yaitu yang berkaitan dengan nilai-nilai karakter yaitu jujur, tidak berbohong, dan mengenal mana yang benar dan yang salah, yang baik dan yang buruk, yang diperintah dan yang dilarang. Pendidikan kejujuran merupakan nilai karakter yang harus ditanamkan pada anak sedini mungkin karena nilai kejujuran merupakan nilai kunci dalam kehidupan. Anak juga harus dididik mengenai nilai karakter benar dan salah, karakter baik dan buruk, dan anak dididik atau dikenalkan apa-apa yang boleh dilakukan dan apa-apa yang tidak boleh dilakukan. Pada usia 7-8 tahun, anak dididik tanggung jawab diri sendiri dan anak juga mulai dididik untuk disiplin, dan lain-lain (Andayani, 2012, hal. 22-23).

Apakah pendidikan karakter merupakan hasil baru dalam pendidikan di Indonesia? jawabannya tidak. Bapa Pendidikan Indonesia, Ki Hajar Dewantara menyatakan bahwa pendidikan merupakan upaya menumbuhkan budi pekerti 
(karakter), pikiran, dan tubuh anak. Ketiganya tidak boleh dipisahkan agar anak dapat tumbuh dengan sempurna. Jadi pendidikan karakter merupakan bagian penting yang tidak boleh dipisahkan dalam isi pendidikan (Hariyanto, 2012, hal. 33).

Sudah jelas bahwa pendidikan karakter sudah diterapkan sejak dulu, akan tetapi karena banyaknya anak yang masih usia belia gampang putus asa, terombang-ambing dari sifat yang tidak baik, pandai berbohong, mudah terbawa emosi, atau bahkan sering melawan orang tua. Itu semua karena sekolah kurang memperhatikan pendidikan itu berdampak terhadap perubahan perilaku yang berkarakter baik dan berakhlak mulia. Semestinya dengan pendidikan selama 6 tahun, lulusan Sekolah Dasar sudah terbentuk karakter/akhlak yang baik. Namun pada kenyataannya belum sesuai dengan yang diharapkan karena masih banyak anak-anak dengan jenjang SD, SMP, hingga SMA yang terlibat dalam hal-hal negatif.

Contoh kasus yang terjadi di Sulawesi Selatan, pelajar kelas 6 SD dibakar oleh dua orang anak yang masih duduk dibangku SMP, pelaku menyiramkan bensin ke tubuh korban kemudian menyulut korek api kepada korban (Linggasari, 2015); kasus lain yang terjadi di Jakarta Timur, anak berusia 7 tahun melakukan pencabulan kepada anak perempuan berusia 5 tahun (Putih, 2015); selain itu, di Banyumas Jawa Tengah, 8 orang pelajar yang berusia 13 tahun tertangkap tangan saat mereka mencuri pedrol rel KA dan masih menggunakan seragam sekolah karena mereka mencuri saat jam istirahat sekolah (Eviyanti, 2014, hal. 8); kasus lainnya yang terjadi di Cinere Depok, anak SD melakukan pembunuhan berencana terhadap temannya, hanya gara-gara masalah
HP korban bernama Syaiful yang hilang. Pelaku memang sudah dikenal anak yang sering mencuri barang milik temannya dan sering meminta uang teman-temannya. Pelaku membawa pisau belati besar di dalam tas sekolahnya dan menusuk Syaiful, ada 8 tusukan ketubuh Syaiful dibagian perut, paha, betis, tangan, kemudian korban diseret dan membuangnya ke selokan dekat sekolah (Annisa, 2012); dan yang lagi maraknya kejahatan begal kendaraan bermotor yang merebut motor korban dan membawa pedang di tangannya, hampir rata-rata kejahatan begal ini dilakukan oleh remaja usia belia. Kejadian ini terjadi di Pondok Aren Subang. Masih banyak lagi contoh kasus lainnya.

Begitulah realita yang terjadi, masih banyak anak-anak hingga remaja yang terlibat perilaku negatif. Melihat fenomena di masyarakat tentang kejadian tersebut, peneliti merasa prihatin dan ikut bertanggungjawab akan generasi di masa depan. Hal ini menandakan bahwa pendidikan karakter belum memberikan hasil yang baik. Oleh karena itu ada beberapa penyebab, yaitu (1) sekolah yang belum maksimal dalam pelaksanaan pendidikan karakter, (2) pengaruh dari lingkungan di luar lembaga pendidikan, (3) bahkan peran guru sendiri yang kurang memahami akan pentingnya karakter yang berdampak besar pada sikap anak. Di sisi lain pemahaman dan penguasaan guru tentang pendidikan karakter, membantu dalam membentuk karakter peserta didik dengan cara memberikan contoh keteladanan yang baik seperti, berbicara yang sopan, toleransi, kejujuran, dan lain sebaginya. Itulah salah satu faktor penyebab dalam pembentukan karakter yang belum maksimal. 
Dalam permasalahan tersebut, terdapat sub masalah dalam pembentukkan karakter. Pelaksanaan pendidikan karakter menjadi salah satu hal yang harus dilaksanakan di jenjang pendidikan manapun, khususnya di jenjang pendidikan dasar.Hal ini dikarenakan pendidikan dasar menjadi pondasi utama bagi tumbuh kembangnya generasi muda dimasa depan. Pada saat ini, nilainilai pendidikan karakter sudah mulai diimplementasikan di sekolah dalam berbagai mata pelajaran, khususnya dalam mata pelajaran Pendidikan Agama Islam.

Menurut Syahidin (2009, hal.3), pendidikan agama Islam lebih dititikberatkan pada pembinaan kepribadian siswa bukan hanya pada pengembangan wawasan tentang pengetahuan agama Islam semata. Pendidikan agama Islam di sekolah hendaknya mengarah pada pembinaan akhlak yang baik.

Sudah jelas bahwa dengan pendidikan agama Islam berusaha untuk membentuk manusia yang berkepribadian kuat dan baik yang berdasar pada ajaran agama Islam. Pendidikan Agama Islam harus diberikan sejak dini, mulai usia kanak-kanak, remaja, bahkan dewasa. Berdasarkan pra survey, peneliti berasumsi di SDIT Lukmanul Hakim telah melakukan pendidikan karakter dengan salah satu indikasinya adalah perilaku sopan santun. Untuk membuktikan asumsi tersebut, peneliti akan mengungkap indikasi lainnya sehingga menjadi informasi yang utuh. Untuk menjawab pertanyaan tersebut, perlu diteliti dengan mengangkat judul

"Implementasi
Karakter dalam PAI di SDIT
Lukmanul Hakim Arcamanik
Bandung".

\section{METODE}

Dalam penelitian ini peneliti menggunakan desain penelitian studi deskriptif. Penelitian studi deskriptif ini, menghasilkan data kualitatif yang sifatnya deskripsi berupa ucapan, tulisan atau perilaku yang dapat diamati sesuai dengan fakta di lapangan dan hasilnya akan dianalisis.

Alasan peneliti menggunakan studi deskriptif adalah peneliti lakukan karena ingin mendapat informasi berupa peristiwa ataupun aktifitas yang terdapat di SDIT Luqmanul Hakim mengenai pendidikan karakter dalam PAI, dengan menggunakan berbagai sumber data. Peneliti menggunakan berbagai sumber data untuk mencapai validitas dan reabilitas dalam penelitian.

Penelitian dilakukan di SD Islam Terpadu Luqmanul Hakim yang berlokasi di Jalan Cingised Kav. D13D15 Kel. Cisaranten Endah Kec.Arcamanik Bandung 40295. Adapun yang ikut berpartisipan diantaranya kepala sekolah, wakil kepala sekolah, guru dan siswa. Peneliti hanya meneliti siswa kelas 15 saja, dikarenakan untuk kelas 6 tidak ada pembelajaran dan sedang fokus untuk Ujian Nasional.

Teknik pengumpulan data merupakan cara yang ditempuh dalam mengumpulkan data-data yang dibutuhkan untuk menjawab masalah dalam penelitian. Teknik pengumpulan data yang digunakan dalam penelitian ini dengan beberapa cara yaitu wawancara, obervasi, dokumentasi, dan uji validitas (triangulasi, member check).

Data yang sudah didapat melalui teknik pengumpulan tersebut, langkah selanjutnya adalah dengan menganalisis data. Data tersebut dianalisis dengan mereduksi data dengan cara memilih data yang penting yang sesuai dengan rumusan 
masalah, setelah itu dikategorisasi dengan menggunakan koding. Data yang sudah direduksi lalu disajikan dalam penyajian data dengan uraian singkat secara deskriptif dan setelah semuanya selesai tahap selanjutnya adalah menyimpulkan.

\section{HASIL DAN PEMBAHASAN}

SD Islam Terpadu Luqmanul Hakim yang berlokasi di Jalan Cingised Komp. Pemda Kav. D13D15 Kel. Cisaranten Endah Kec.Arcamanik Kota Bandung 40295 Telp. 022.70280608. SDIT Luqmanul Hakim sudah terakreditasi A, dengan SK Badan Akreditasi Sekolah No.02.00/533/BAP-SM/IX?2010. dan NSS/ijin operasional 421.2/761Huk/2006.

Visi SDIT Luqmanul Hakim adalah meluluskan siswa-siswi yang cerdas Qur'âni. Adapun Misi SDIT Luqmanul Hakim adalah sebagai berikut : (1) berdakwah melalui lembaga pendidikan,(2) memberikan layanan pendidikan Islami,(3) meningkatkan kualitas pendidikan dengan mengasah kecerdasan intelektual, emosional, dan spiritual siswa,(4)menumbuh kembangkan semangat pembelajaran pada diri setiap siswa-siswi,(4) membingkai setiap aktifitas pendidikan dengan nilai-nilai al-Qur'ân.

$$
\text { Adapun tujuan SDIT }
$$

Luqmanul Hakim adalah (1) membentuk manusia yang memiliki aqidah yang lurus (Salimu Aqidah), (2) membentuk manusia yang beribadah secara benar (Sahihul Ibadah), (3) membentuk manusia yang berahlak mulia (Ahlakul Karimah), (4) membentuk manusia yang berpikiran cerdas, (5) membentuk manusia yang sehat dan kuat, (6) membentuk manusia yang kreatif, inisiatif, dan responsif.
Berdasarkan hasil wawancara, studi dokumentasi, observasi, serta pengamatan langsung yang telah dilakukan oleh peneliti kepada kepala sekolah dan juga guru PAI di SDIT Luqmanul Hakim bahwa perencanaan pendidikan karakter dalam PAI di SDIT Luqmanul Hakim. Di SDIT Luqmanul Hakim menggunakan dua kurikulum, yaitu kurikulum yang ditetapkan dari Dinas Pendidikan dan kurikulum yang ditetapkan dari Yayasan. Adapun indikator pembelajaran yang harus dicapai oleh siswa/siswi adalah terampil menulis huruf Arab, berkomunikasi secara baik, berperilaku sosial yang baik, rajin shalat, hidup bersih, berbakti pada orang tua dan guru, disiplin, mandiri, tartil membaca al-Qur'ân dan hafal 2 juz yaitu juz 29 dan 30 . Perencanaan nilai-nilai karakter ketika pembelajaran di kelas mengacu pada silabus dan RPP PAI, yaitu nilai karakter kejujuran, kerja keras, tanggung jawab, setiakawan, kedisiplinan, kerjasama, dll.

Sedangkan

perencanaan mengenai program-program yang berkenaan dengan nilai karakter yaitu ada program TTQ yang menggunkan metode Ummi, dengan target kelas 13 sudah beres Ummi jilid 1-6, untuk kelas 4-6 sudah al-Qur'ân. Sedangkan untuk hafalannya, kelas 1-4 sudah beres juz 30, dan kelas 5-6 hafal juz 29 dan 30. Diakhir semester ada uji publik juz 29/khataman untuk siswa/siswi yang sudah siap diuji hafalannya. Program lainnya yaitu Mabit untuk kelas 4-6 dalam satu semester melaksanakan 2 kali mabit, dan pesantren kilat yang diadakan di bulan Ramadan. Selain itu ada program pembiasaan yang dilakukan oleh siswa yaitu, 1) mengucapkan salam, 2) makan dan minum sambil duduk, dan 3) membuang sampah pada tempatnya. Pelaksanaan nilai karakter ketika di lingkungan sekolah 
SDIT Luqmanul Hakim, sebagai berikut : 1) nilai karakter religius, yaitu shalat zuhur dan asar berjamaah di sekolah, muraja'ah, membaca alQur'ân; 2) nilai karakter kejujuran, yaitu tidak mencontek ketika ulangan, melapor kepada guru jika menemukan uang atau barang bukan miliknya; 3) nilai karakter mandiri dan tanggungjawab, yaitu dalam mengerjakan tugas yang diberikan, menghabiskan makanan sampai habis, mandiri dan bertanggungjawab merapihkan barang-barang sebelum pulang sekolah; 4) nilai karakter kedisiplinan, yaitu disiplin masuk kelas, disiplin ketika shalat, dan disiplin mematuhi aturan sekolah; 5) nilai karakter peduli lingkungan, yaitu membuat sampah pada tempatnya, menjaga kebersihan kelas dan lingkungan sekolah.

Pelaksanaan program TTQ dilaksanakan mulai jam 07.30-08.30 untuk kelas 1 dan 2, jam 08.30-09.30 untuk kelas 3 dan 4, dan jam 10.0011.00 untuk kelas 5 dan 6. Sebelum memulai pembelajaran TTQ, hal yang dilakukan siswa/siswi yaitu berdoa, membaca Ummi/ al- Qur'ân terlebih dahulu, kemudian muroja'ah bersama-sama. Namun untuk kelas 13 masih dibimbing oleh gurunya dalam membaca Ummi. Sedangkan kelas 4-6 membaca al- Qur'ân secara bersama-sama. Pelaksanaan mabit dilaksanaakan di luar lingkungan sekolah tempatnya di villa neglasari Cimahi, dalam kegiatan mabit tersebut tidak hanya siswa, melainkan orang tua siswa juga ikut terlibat dalam pelaksanaan mabit. Kemudian untuk pelaksanaan pesantren kilat dilaksanakan selama 6 hari dibulan Ramadan dan diakhir acara pesantren kilat, ada ifthor jama'i. Evaluasi ketika pembelajaran di kelas dengan ulangan tertulis maupun lisan. Evaluasi secara keseluruhan dilakukan setiap dua minggu sekali dalam rapat pekanan, dalam evaluasi ini tidak hanya membahas mengenai akademik siswa namun akhlak siswa yang bermasalah dibahas dalam rapat evaluasi dan setiap masalah diselesaikan secara bersama-sama. Selain permasalahan siswa mengenai akademik dan akhlak siswa, dalam evaluasi tersebut permasalahan guru pun dibahas mengenai penilaian, penyusunan RPP, dll.

\section{KESIMPULAN}

Dapat disimpulkan bahwa perencanaan pendidikan karakter dalam PAI di SDIT Luqmanul Hakim, dalam pembelajaran PAI di kelas sesuai dengan silabus dan RPP PAI. Namun tidak ada perbedaan dalam silabus dan RPP PAI. Nilai pendidikan karakter seperti nilai karakter religius, kedisiplinan, mandiri, kejujuran, saling menghargai, tanggung jawab, kerjasama, dll, hanya diterapkan secara langsung dalam setiap sub bab ketika pembelajaran PAI. Adapun pembiasaan mengenai 3 hal yang harus dilakukan oleh siswa yaitu pembiasaan mengucapkan salam, makan dan minum sambil duduk, dan membuang sampah pada tempatnya.

Secara umum disimpulkan bahwa pendidikan karakter dalam PAI di SDIT Luqmanul Hakim sudah cukup baik. Hal tersebut terlihat dari siswa/siswi yang sudah membiasakan 3 hal, yaitu mengucapkan salam, makan dan minum sambil duduk, dan membuang sampah pada tempatnya. Pembiasaan nilai-nilai karakter baik ketika pembelajaran di dalam kelas maupun disekitar lingkungan sekolah sudah baik. Terlihat dari siswa yang melaksanakan shalat dzuhur berjamaah di masjid dan sebelum pulang sekolah shalat ashar terlebih dahulu di sekolah. selain tu, menjaga kebersihan kelas dan lingkungan 
sekolah, saling menghargai sesama teman, tanggung jawab dengan tugas yang diberikan, disiplin dengan aturan yang diberikan dan berani menerima konsekuensi jika melanggar aturan, dll. Guru-guru SDIT Luqmanul Hakim sudah memahami mengenai pendidikan karakter, sehingga guru beserta staf memberikan teladan yang baik kepada siswa/siswi SDIT Luqmanul Hakim.

Bentuk evaluasi yang dilakukan ketika pembelajaran di kelas yaitu berupa ulangan secara lisan ataupun tulisan, dan pengamatan langsung sikap siswa/siswi selama pembelajaran di kelas. Selain itu adanya buku penghubung dari sekolah kepada orang tua untuk mengontrol setiap perilaku siswa. Sedangkan evaluasi secara keseluruhan adanya evaluasi pekan mingguan, untuk minggu ke-1 dan ke3 rapat evaluasi, dalam rapat tersebut tidak hanya membahas akademik siswa melainkan setiap permasalahan siswa dalam belajar dan akhlak siswa dibahas dan diselesaikan secara bersama-sama. Minggu ke-2 dan ke-4 semua guru beserta staf belajar mengaji bersama. Adapun evaluasi untuk TTQ, diakhir semester ada uji publik (khataman), siswa/siswi diuji hafalannya juz 29, sedangkan untuk evaluasi di kelas dengan adanya buku evaluasi.

\section{REFERENSI}

(2002). Al-Qurān dan Terjemahannya, Penerjemah Tim Depag RI. Jakarta: CV Darus Sunnah

Departemen Pendidikan Nasional. (2007). Pedoman Penyelenggaraan Pendidikan untuk Peserta Didik Berkecerdasan Istimewa (Program Akselerasi). Jakarta:
Direktorat

Pembinaan

Pendidikan Luar Biasa.

Andayani, dkk. (2012). Pendidikan Karakter dalam Perspektif Islam. Bandung: Remaja Rosdakarya.

Annisa, I. (2012, Februari Sabtu). Anak SD melakukan pembunuhan berencana terhadap temannya. Dipetik Juli Sabtu, 2015, dari www.kompasiana.com.

Eviyanti. (2014). 8 Pelajar Mencuri Pedrol Rel KA. Bandung: Pikiran Rakyat.

Hariyanto, dkk. (2012). Pendidikan Karakter. Bandung: PT. Remaja Rosdakarya.

Hariyanto, dkk. (2012). Pendidikan Karakter. Bandung: PT. Remaja Rosdakarya.

Linggasari, Y. (2015, 04 Kamis). Pelajar kelas 6 SD dibakar. Dipetik Juli Jum'at, 2015, dari m.cnnindonesia.com.

Syahidin. (2009). Menelusuri Metode Pendidikan dalam al-Qur'an. Bandung: Alfabeta. 